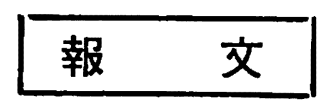

\title{
赤変小麦及び黒変大麦について \\ On the Red Discolored Wheat and Black Discolored Barley
}

（昭和 35 年 4 月 18 日受理）

\author{
小林邦彦末次重一 \\ (Kunihiko Kobayashi) (Shigekazu Suetsugu)
}

1. Ghicken, young rats, and pregnant rats and their weanlings have been fed on the rations containing a large quantity of the powder of red discolored wheat. There were no effects on the growth, distribution of viscera organs and pregnancy of animals.

2. An alcoholic extract of the red discolored wheat has been prepared and given to young rats in amount equivalent to about 25 grams of the red discolored wheat, per head. In this case, the growth of rats has been depleted and the content of non protein nitrogen in their livers has increased.

3. The alcoholic extract has been separated into ether soluble and insoluble fractions. The former fraction has shown the same maximum absorbance and peroxide values compared to the same preparation fiom normal wheat, except for the carotenoids which were absent in the preparation from discolored wheat.

4. The content of histamine in the ether insoluble fraction was very little.

5. Black discolored barleys contained higher amount of amide and reducing sugar.

緒 言

滈温多湿の地区では大小麦が赤変しあるいは黒変し て,その品質を著しく低下し，まれに中毒を起すこともあ る。一般に䧫実が赤変するのは一種のカビに原因するこ とが多く，麦類の赤変については苔干の研究報告があ る。杤内1にによればソ連では1891年 Woronin が赫かび 病麦類で製したパンにより人が中毒した例を記し，その 後 Pomashii あるいは Namov 等により被害款粒の毒 性について研究がなされたという。欧州では主として米 国より輸入した麦類にこの被害を受けたものがあり問題 になった。米国では1928年中西部に大発生をみ，多くの 研究がなされた。それらの結果を要約するこ次の如くで あった。

䞑び麦による中毒は，馬・豚・犬・ネズミに著しく

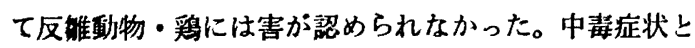
しては食欲減退・吐気・嘬吐・体重の堿少等が観察され た。まだ一般に赤かび病被害教粒の含有率が $10 \%$ 以下の ものは家畜の铝料として使ってよいが，飼料の募沸・梼 蜜の添加では何等その有害性を減ずることはできなかっ た。

このような毒物の本体は未詳であるが Dickson 等5) は一種の配糖体あるいは㙁基性空素化合物であろらと
し，Popp(i) は有毒蛋白犋あるいは有害窒素化合物が生 成されるのであろうとし, Schroeter 等7)はコリンかコ リンの能肪酸エステルであ万うと報告した。高橋・白 浜8)も非蛋白態空素が多くなり，コリン及びアミンが検 出され，また脂肪酸も変犋しリソンレシチン類似物犋を認 めたと報告した。

わが国では眧和 7 年北海道の燕春に大発生をみ，馬の 喰わ嬿麦として問題になった9)。最近では昭和 21 年東 京都内の配給小麦粉によって食中毒が発生し，その原因 として小麦粉から赤かび病の原因菌である Fussarium 属の 1 種を分離しこれが中毒に関与しているという報 告10)があった。

筆者等は北九州において採取した赤変小麦と墅変大麦 について若下の実験を行ったのでここにその成績を報告 して抽きたいと思う。

\section{供 試 材 料}

A 赤変小麦：昭和32年春北儿州各地に発生したもの である。外形は普通の小麦と同様であったが，かすかに 表面の赤変した粒子が混って抢り，その赤変粒子は約18 \%を占めていた。これをそのまま粉砕して用いた。

B 黑变大麦：昭和30年頃北九州で得られたもので黒 変しあるい汢若干醴酵したものであった。よく乾かして 
供試した。

\section{動 物 試 験}

\section{A 中ひなによる試験}

体重約 $400 \mathrm{~g}$ の健全な中ひな16羽を 2 区に分けて50け 開飼育訊検を行なった。

給リ゙した飼料の配公比は表1に示した。

表 1 中ひなに上る試験：飼料配合比 $(\%)$

\begin{tabular}{|c|c|c|c|c|}
\hline & & & 赤变麦粉食区 & 㕕米粉食区 \\
\hline 少 & 米 & 粉 & - & 71.5 \\
\hline 赤 & 变 娄 & 粉 & 71.5 & - \\
\hline$\Rightarrow$ & プラ 粕 & 粉 & 20.0 & 20.0 \\
\hline 奥 & & fo & 5.0 & 5.0 \\
\hline$y$ & 口 1 力 & ル & 3.0 & 3.0 \\
\hline 食 & & 鼔 & 0.5 & 0.5 \\
\hline
\end{tabular}

この外に毎日青菜を飼料100につき20添加して与えた。 50 日閏の体重增加を表 2 に示した。

表 2 中ひなに上る試验：成長

\begin{tabular}{cccc}
\hline 8 & 羽平均 & 赤变麦粉食区 & 立米汾食区 \\
\hline 初体 重 $\mathrm{g}$ & 4112 & 403 \\
50 日後体重 & $\mathrm{g}$ & 1190 & 1132 \\
50 日間增重 & $\mathrm{g}$ & 788 & 729 \\
增 可 比 & 108 & 100 \\
\hline
\end{tabular}

このように赤変麦粉食を与えた方が去米食を与えたも の上り僅かではあるが却って成長がよい上うであった。

Mundkur 等2は赫び茂在成舅に与えても中毒はなく

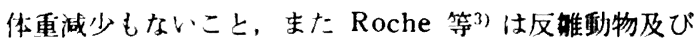
家禽に激しくおかきれた赤かび麦古与えても覀影然のな いことを報告してい\%。しかし前記 Mundkur 等は2 週 間令のひなに与えると体車が減少し羽毛が立ってくるこ とを锶繁している。一方 Mains 等山は解化後 8 週閂の 若㘪及びひなを 5 週問飼育した結果無病大麦を与えた動 物と比べて差のないことを報告している。いずれにして もわれわれが使用した程度の赤变麦は熖に対しては毒性 がないれのと思われた。

表3中ひなに上る試験：内臟分布(体重に対する\%)

\begin{tabular}{|c|c|c|c|}
\hline \multicolumn{2}{|c|}{ ( 3 羽平均) } & 赤变哆粉食口 & 立米粉食区 \\
\hline 心 & 䓡 & 0.64 & 0.61 \\
\hline 肺 & 茷 & 0.78 & 0.81 \\
\hline 肝 & 腧 & 2.68 & 2.73 \\
\hline 督 & 蔽 & 0.93 & 0.93 \\
\hline 脾 & 歲 & 0.12 & 0.17 \\
\hline 睡 & 丸 & 0.09 & 0.08 \\
\hline
\end{tabular}

また 50 日閣飼育後备区から代表的なもの 3 羽をとって
解体して内䓰を検しかつその分布を比較した。その結果 は表 3 に示すように殆ど差はなく，また各組織の肉眼的 観察においても何等異常は認められなかった。

\section{B 幼いネスミによる試糇}

体重約 $90 \mathrm{~g}$ の幼い白ネスミの雄10頭を 2 区に分け夏棃 40日閣飼育した。給与した飼料の配台比を表 4 に示し た。これを水でねって蒸慐して与えた。

表 4 幼ネズミに上る社缓：飼料配合比(\%)

\begin{tabular}{|c|c|c|}
\hline & $1 \square$ & 2 区 \\
\hline 洂 変麦 粉 & 78 & 78 \\
\hline 粉 & 20 & 10 \\
\hline 肝 & - & 10 \\
\hline マッカラム盐 & 1 & 1 \\
\hline$=\square 1$ カ & 1 & 1 \\
\hline
\end{tabular}

青菜与えす

40 日間飼盲した絬果は表 5 に示すように何等異常なく Donaldson ${ }^{11}$ によるネズミの標準成長（飼料はミルク浸 しトウモロコシパンである）に比べて何等少るところは なかった。

表 5 幼ネズミに上る鞓跧：成長

\begin{tabular}{cc|r|r|r|r}
\hline 雄 5 頭平均 & 1 & 区 & 2 & 区 & $\begin{array}{c}\text { 模 } \\
\text { (Donaldson) }\end{array}$ \\
\hline 初 体 重 & $\mathrm{g}$ & 95 & 94 & 94.5 \\
40 日後体重 & $\mathrm{g}$ & 213 & 235 & 174.0 \\
40日間增重 & $\mathrm{g}$ & 118 & 141 & 79.5 \\
\hline
\end{tabular}

なお肝粉を給与したものの方が成長がよかった。しか しこれはこの実験では青菜を与えていないので肝粉中 のビタミン類の効果と考えられた。

\section{C 好娠ネスミ及びそのタネスミによる試験}

冬季，妊娠ネズミ2 頭を各々分婏箱に移し赤変麦粅 9 魚粉 1 の混合飼料を水でねって蒸意して十分に与え，か つ青菜も十分に与えて飼育した。その結果分婏哺乳も正 常でよく仔ネズミを育てた。分婏仔ネズミは各々8 頭で あった、この伓ネズミを乳離れ後更に前記赤変麦飼料で 饲育した。その結果は表 6 のようで何等異常は裙められ なかった。

表 6 赤变麦給与トスミから生まれた仔ネス:の成長試硢

\begin{tabular}{|c|c|c|c|c|}
\hline & 方 4 頭 & $\begin{array}{l}\text { 일 } 12 \text { 頭 } \\
\text { 平均 }\end{array}$ & $\begin{array}{l}\text { o Donald- } \\
\text { son 權望 }\end{array}$ & $\begin{array}{l}\text { 9. Donald- } \\
\text { son 榡淮 }\end{array}$ \\
\hline 初 体 重 $\mathrm{g}$ & 50.3 & 57.7 & 50.6 & 57.5 \\
\hline 60日後体重 $\mathrm{g}$ & 157.3 & 131.8 & 172.7 & 155.3 \\
\hline 60 日間增重 $\mathrm{g}$ & 107.0 & 74.1 & 122.1 & 97.8 \\
\hline
\end{tabular}

前記の標準成长と比べとやや劣るがこれは冬季の試 験であったからと考えられた。 
Mains 等4は赤かび麦はネズミに対して有等で，赫 び麦の表に特に敏感であると報告している。しかし彼ら

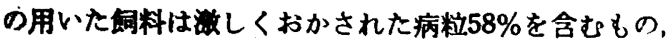
あるいは怪度の病粒 $64 \%$ を含むものであった。われわれ が使用した程度の赤変麦ではネズミに毒性を示さないし， のと思われた。

\section{D アルコール浔出物をネスミに与えた試験}

赤変麦粗粉12kgを12lのアルコールで2回浸出し，浸出 液からアルコールを娍圧下 $60^{\circ} \mathrm{C} て ゙$ 除き褐色油状物 $500 \mathrm{~g}$ を得た。その収事は約 4 \%であった。この浸出物を幼、 ネズミ体重約 $100 \mathrm{~g}$ のものに与えて試験を行なった。基 本玍司料として精白麦炤 94 ，緑葉粉 5 ，コロイカル 1 ，な る眍合比(\%)のしのを使用した。この飼料の蒸募したも のに 1 日 1 頭につき浸出物 $1 \mathrm{~g}$ を添加し給与した。これ は原料赤変表に換算すると25 gにあたり，若いネズミの 满腹量の 2 倍にあたるものを食べさせたことになった。 若、睢ネズミ10頭を基本飼料区と浸出物添加区に分け， 40日間飼育した。なおその，間．終りの15日間をとり，食 下量，消化率，飼料能事を測定した。その結果を表 7 亿 示した。

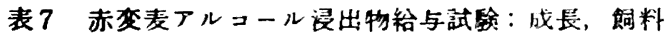
能率及び消化率

\begin{tabular}{|c|c|c|c|c|}
\hline （95 頭平均） & & & 照 区 & $\begin{array}{l}\text { アルコール } \\
\text { 浸出物区 }\end{array}$ \\
\hline 初 体 重 & g & & 97.2 & 97.4 \\
\hline 40日後体重 & g & & 155.8 & 137.6 \\
\hline 40日間增重 & $g$ & & 58.6 & 40.2 \\
\hline 増重 率 & $\%$ & & 60.3 & 41.3 \\
\hline 同.上比 & & & 100 & 68 \\
\hline 15日間食下量* & g & & 217.4 & 174.4 \\
\hline 初 体 重 & g & & 131.0 & 120.8 \\
\hline 15日後体重 & g & & 155.8 & 137.6 \\
\hline 15日間増重 & $g$ & & 24.8 & 16.8 \\
\hline 䞒料能率* & $\%$ & & 11.4 & 9.6 \\
\hline 同上比 & & & 100 & 84 \\
\hline 消化率* 蛋白夏 & $\%$ & & 68.3 & 68.0 \\
\hline 螗 紫 & $\%$ & & 94.1 & 95.4 \\
\hline 压 分 & $\%$ & & 64.6 & 71.1 \\
\hline 有機物 & $\%$ & & 87.0 & 87.5 \\
\hline
\end{tabular}

*实䟻後期の15日間について食下量，飼料能率 $\left(\frac{15 \text { 日間增重 }}{15 \text { 日間食下 }} \times 100\right)$ ，消化率を测定した。

表によって明らかなように対照に比べて赤変麦アルコ 一ル浸出物を与えたものの方が成長がおくれ，饲料能率 も低くなった。しかし，蛋白澌，䊀分，灰分，有機物の 消化率には変化がなかった。
40日間飼育後解体し内腆分有亚びに肉服的㽙察を行な ったが表8に示すように，いずれも異常は慜められなか った。

表 8 アルコール浸出物給与ネズミの内瀻分布

（対体重\%)

\begin{tabular}{|c|c|c|c|}
\hline 葴 & 器 & 対 照 区 & $\begin{array}{l}\text { アルコール } \\
\text { 浸出物区 }\end{array}$ \\
\hline 心 & 膨 & $0.388 \pm 0.033^{*}$ & $0.396 \pm 0.022^{*}$ \\
\hline 肺 & 㖑 & $0.701 \pm 0.112$ & $0.689 \pm 0.052$ \\
\hline 肝 & 睵 & $3.036 \pm 0.160$ & $3.231 \pm 0.121$ \\
\hline 脾 & 臟 & $0.236 \pm 0.019$ & $0.211 \pm 0.022$ \\
\hline 堅 & 臟 & $0.632 \pm 0.049$ & $0.698 \pm 0.023$ \\
\hline 卵 & 柴 & $0.241 \pm 0.031$ & $0.242 \pm 0.022$ \\
\hline
\end{tabular}

* Standard error of the mean

また肝臟・筋肉についてー般成分の分析を行なった結 果表 9 のように肝䑏中非蛋白態空素が対照より多犺った ほかは顕著な差はなかった。

表 9 アルコール浸出物給与ネズミの血色素量 及び肝莃・筋内成分

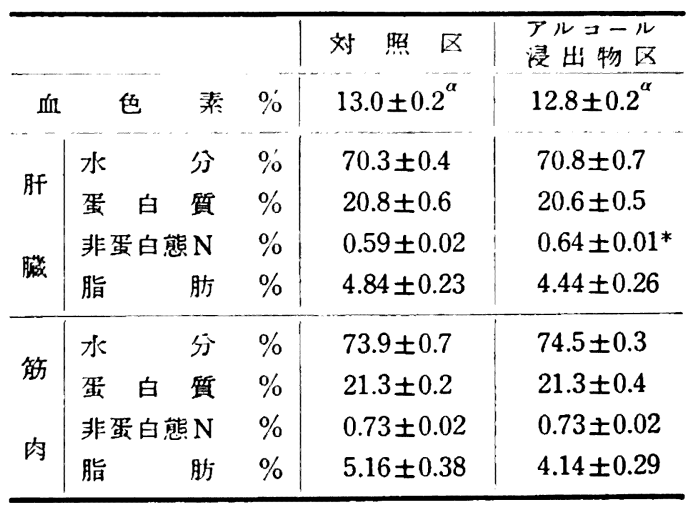

a) Standard error of the mean

* $\mathrm{P}<0.05$

成分

\section{A 黑変大麦と酸瞵黒変した大麦の一般組成} 表10に示すようであった。

表10 熙变大麦，酸醉黑変大麦の一般組成

\begin{tabular}{|c|c|c|c|c|c|}
\hline \multirow{2}{*}{ 成 } & \multirow{2}{*}{ נ八 } & \multicolumn{2}{|c|}{ 黑変大麦 } & \multicolumn{2}{|c|}{ 酮醇照変大麦 } \\
\hline & & No. 1 & No. 2 & No. 3 & No. 4 \\
\hline 蛋 白 㑭 & $\%$ & 10.84 & 8.96 & 6.34 & 7.53 \\
\hline 純蛋白質 & $\%$ & 6.43 & 6.23 & 4.55 & 5.29 \\
\hline アマイド類 & $\%$ & 4.41 & 2.73 & $\cdot 1.79$ & 2.24 \\
\hline 粗 没 粉 & $\%$ & 62.23 & 64.06 & 78.84 & 67.61 \\
\hline 覆 元 煻 & $\%$ & 8.50 & 8.98 & 3.98 & 3.50 \\
\hline
\end{tabular}

B 赫小麦のアルコール漫出物

先に述ベたアルコール浸出物をエーテル可溶部と不溶 
部に分けて研究した。

エーテル可溶部について最大吸収をべックマン分光光 度計を用いて測定した。その結果 $274 \sim 282,320,650 \mathrm{~m} / \iota$ の 3 個所に最大吸収があった。別に正常小麦を同礿に处 理して得たエーテル可溶部には 274〜282,320,420,444, $472,665 \mathrm{~m} \mu$ の 6 個所に最大吸収があった。274 282, $320 \mathrm{~m} \mu$ の吸収は油脂の不飽和脂肪酸の吸收であり, 420 , $444,472 \mathrm{~m} \mu$ の各部位はカ口チノイドの吸收と推定され た、赤変麦の浸出物ではこのカロチノイドが䣬化されて いたと考えられた。な拉 $650 ， 665 \mathrm{~m} \mu$ の吸収は不辣であ る。

エーテル可溶部のエーテルを去り油分をとって過酸化 物価を測定した結果，赤变麦浸出物で13，正常麦で 3 で あったっこの価は正常麦より注明らかに高いが毒作用在 あらわすほどではなかった。

水溶部についてはヒスタミンを測定した。その結果，

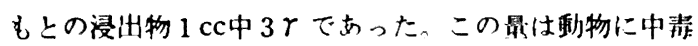
を抗こすほどてはなかった。

\section{要䄪}

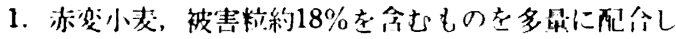

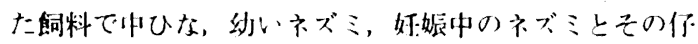

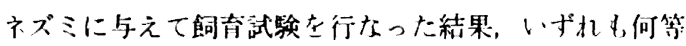
哄常はなく濇性は認心的机なかった。

2. 赤変小麦のアルコール浸特物(アルコールを除いた

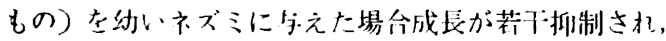

肝哓の非蛋白態営秦が增加した。

3.アルコール浸出物をエーテル可溶部と不溶部に分 け，エーテル可溶部の最大吸収, 油の過酸化物㑑，また 不溶部のヒスタミン量を測定した結果大差は認められな かったが，カロチノイドは赤変小娄浸出物中には㱠ど照 められなかった。

4. 黒変大麦ではアマイド類及び楉分の增量が認められ た。

（付記）この実伢に当って佐道鈴子，石川幹男洏君の 觉を煩わした。ここに記して勒意を表する。

\section{文嶰}

1) 栃内; 病蛙客新, 20, 106 (昭和 8 年)

2) B. B. Mundkur and B. L. Cochran; Phytopath. 20, 132 (1930)

3) D. H. Roche, G. Bohstedt, and J. G. Dickson ; Ibid. 20, 132 (1930)

4) E. B. Mains, C. M. Vestal, and P. B. Curtis ; Proc. Indiana Acad. Sci. 39, 101 (1930)

5) A. D. Dickson, K. P. Link, B. H. Roche and J.G. Dickson ; Phytopath. 20, 132 (1930)

6) M. Popp and J.Contzen; Tierernähr. 2, 315 (1930), C. A. 28, 1298 (1931)

7) G. Schroeter and L. Strassberger; Biochem. Z. 232, 452 (1931)

8）高橋・白浜；札愢费林会報 25, 375 (1934)

9) 析内；病虫害誌 20,179 (昭和 8 年)

10）平山・刅本；衛生研報 66 号 85 (1948)

11) H. H. Donaldson; The Rat : Data and Reference Tables for the Albino Rat and Norway Rat. (1924)

（九州大学患学部栄養化学）

脱脂トライミルクと製パンへの利用

脱脂ドライミルクは乾燥前に十分加熱処理すると，末 処理のものを使用した場合に現われる欠点を除きドウの かたさや膨張度を改善することがでる。6\%のドライ ミルクを使用した場合，混揘時間は変化しないがドゥの 組織か强固になり，過剩混捏の害があらわれにくい。ミ ルクは緩衙作用が強いのでドウ酸醉の際の $\mathrm{pH}$ の低下゙を 妨げる。これは榶分解，蛋白分解醉素の作用を低めるこ とになるが反面イーストフードの効果を增進し，またド ウを辰時閏酸䤊させても優れた製パン性を保持させる。 脱脂ドライミルクを玑えたドウは組織の状態が一定で分
㓝が均一に行われる。ホイロの湿度は低目がよく烧上時 間は十分かける必要がある。食パン用には $6 \%$ ，その他 のケーキ類には $10 \sim 16 \%$ の使用が適当である。なお， はしめに最近の脱脂ドライミルク製造の傾向から製法製 品組成にもふ九ている。

Nonfat Dry Milk and its Llse in the Bakery B. W. Fairbanks

Bakers Digest 34, No. 2, 52 (1960) (津 村) 